\title{
'Two Million Net New Jobs': A Reconsideration of the Rise in Employment in South Africa, 1995-2003
}

\author{
Daniela Casale \\ Division of Economics \\ University of Kwa-Zulu Natal \\ casaled@nu.ac.za \\ Colette Muller \\ Division of Economics \\ University of Kwa-Zulu Natal \\ mullerc2@nu.ac.za \\ Dorrit Posel \\ Division of Economics \\ University of Kwa-Zulu Natal \\ posel@ukzn.ac.za
}




\section{Abstract:}

In this paper we investigate labour market trends in South Africa between October 1995 and March 2003. In particular, we evaluate the South African government's claim that over this period, the economy created two million net new jobs. Using the same household survey data as that used to generate official employment estimates, we also find an almost two million net increase in employment. However, we show that this increase is likely to have been inflated by changes in data capture and definitions of employment over the years, and that the real increase may be considerably less, with a lower bound of approximately 1.4 million jobs. We argue further that the rise in employment over the period must be evaluated in the context of a dramatically larger growth in labour supply and therefore rising rates of unemployment, declining real earnings, and an increase in the number of the working poor, particularly among Africans.

\section{Acknowledgements:}

This paper has been published in The South African Journal of Economics, Vol. 72:5 Desember/December 2004.

Development Policy Research Unit

Tel: +2721650 5705

Fax: +2721650 5711
Information about our Working Papers and other published titles are available on our website at: http://www.commerce.uct.ac.za/dprul 


\section{Table of Contents}

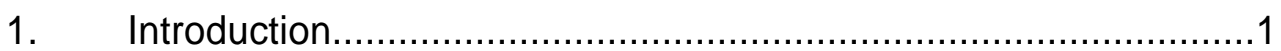

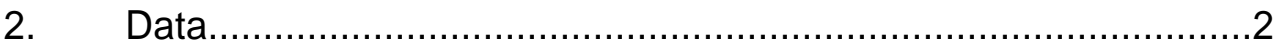

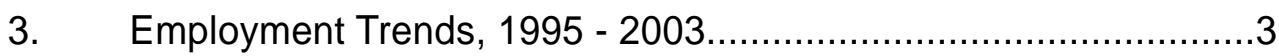

(a) A two million net increase in employment?..................3

(b) Where has employment increased?........................... 7

(c) The increase in labour supply...............................

4. Implications of the Increase in Employment.............................10

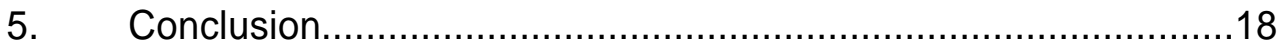

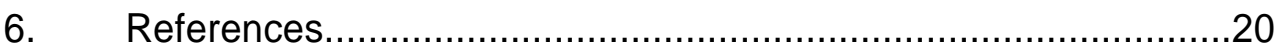




\section{Introduction}

There has been much debate in South Africa over the past decade concerning national employment and unemployment statistics (see, for example, Standing et al, 1996; Bhorat, 1999; Klasen and Woolard, 1999; Schlemmer and Levitz, 1999; Nattrass, 2000). This followed the introduction in the 1990s of household surveys that for the first time in the country captured detailed information on individual employment status. The debate about statistics intensified more recently in the run-up to the 2004 national election. The statement by the ANC government that "the economy created two million net new jobs since 1995" based on these surveys, in particular provoked considerable discussion in the media as to whether these trends are credible. ${ }^{1}$

With the growing recognition of very high (and increasing) rates of unemployment in the country, and reports of firms engaging in large-scale retrenchments, it is perhaps not surprising that statistics, which suggest an increase in employment of this magnitude, are met with controversy and disbelief. Furthermore, in 2000 a new household survey (the Labour Force Survey) was introduced which was designed to capture all forms of work with greater efficiency. More specifically, increased emphasis was placed on classifying as employed those engaged in informal activities and small-scale agriculture, even if for only one hour in the previous week. This has confounded the debate because it could be argued that the increase in employment is not real, but rather is an artefact of changing definitions and improved data collection.

Our objective in this paper is to evaluate the claim that two million net new jobs were created between 1995 and 2003, drawing on the same data sources as those used to generate official estimates on employment. We begin by assessing the validity of this finding, given the problems with measuring employment status consistently across the years using national household survey data. We show that, taken at face value, recorded employment did indeed increase by close to two million jobs over this eight-year period. Even if a sizeable part of this increase is real, however, we explain why it is very likely that some (not inconsiderable) portion is the result of changes in definitions and data capture.

\footnotetext{
1 See "Employment I: We need a people's contract to create work" and "Employment II: The myth of jobless growth" (ANC Today, Volume 4, No. 9, 5-11 March 2004); "The debate on the President's State of the Nation Address" (Speech by Minister of Labour MMS Mdladlana in Parliament, 10 February 2004, Cape Town); and "Doomsayers take liberties with facts on employment" (Minister of Trade and Industry Alec Erwin, Sunday Independent, Business Report, 15 February 2004). And in response: "Unions and researchers slam government over claims of jobs growth" (Terry Bell, Published on the Business Report website, 15 February 2004); "Erwin digs in his heels on job increase data" (Quentin Wray, Published on Business Report website on 23 February 2004); and "DA rubbishes ANC jobs claims" (Nic Dawes, This Day, 8 March 2004).
} 
We argue further that in evaluating the government's claim of job creation there are other factors, beyond the verification of statistics, which need to be highlighted for a more complete picture of labour market trends in South Africa. This paper adds to the debate by exploring three of these: the types of employment that have increased; the magnitude of the employment increase in relation to the growth in labour supply; and the changes in earnings that have accompanied the rise in employment.

\section{Data}

Labour market analysts are generally in agreement that the most accurate way of measuring employment status in South Africa is through the national household surveys conducted by Statistics South Africa (SSA) - the October Household Survey (OHS), an annual survey conducted from 1993 to 1999, and the Labour Force Survey (LFS), a biannual survey introduced in 2000 . The two other sources from which labour market statistics have been drawn are the population census and the Survey of Employment and Earnings (SEE). Both of these latter sources however are not suitable for a comprehensive analysis of the labour market over time.

The population census, which covered all households in South Africa in a representative manner in 1996 and 2001, does not include detailed questioning on an individual's labour market status. Also, the few questions asked changed quite substantially between 1996 and 2001, making comparisons over the period very difficult. For example, a distinction between formal and informal employment is only drawn in the 2001 census.

The SEE, conducted since $1998^{2}$, attempts to capture employment from the firm side. Before 2002, however, an outdated sample of firms was covered such that employment growth in rapidly expanding sectors (information technology, for example) was not picked up. In 2002 the sample of firms was redrawn to take into account the changing structure of the economy (SSA, 2000; 2002). Another key downfall of the SEE is that only formal (registered) non-agricultural businesses are sampled and therefore no information on informal, agricultural and domestic work is captured. As we show in Section 2 below, these types of employment constitute a substantial part of total employment in South Africa, and the SEE consequently cannot be used to identify trends in aggregate employment.

$2 \quad$ The SEE was piloted in the third quarter of 1997 and was "in operation from the first quarter in 1998" (SSA, 2004:4). 
While the national household surveys conducted by SSA are considered to provide the most reliable and comprehensive picture of the South African labour market from the 1990s onwards, there are still problems with the surveys. The most significant of these for a study of employment trends is that questions relating to an individual's employment status changed over the years and particularly with the crossover to the LFS in 2000. The LFS provides a far more detailed explanation of what constitutes a job, with the aim of capturing irregular and informal work more thoroughly than was the case in the OHS. The LFS questionnaires have emphasised in particular that all small-scale activities should be classified as work, even if the individual was engaged in the activity for only an hour in the previous week. Any study of labour market trends in South Africa should recognise therefore that included in the LFS employment numbers are a group of workers that previously would have been classified as unemployed or inactive.

Although most of the changes in survey design came with the introduction of the LFS, some changes were also made within the OHS series that complicate the comparability of these data sets. In the earlier OHSs (up to the 1995 survey), no prompt was provided for respondents explaining what should be viewed as work; from 1996, a prompt was included. Importantly, as part of the description of what counts as work, the later OHSs specified that own-account farming ${ }^{3}$ should be reported as employment (Muller and Posel, 2004). We would expect, therefore, that the later OHS employment estimates would include, in particular, subsistence farmers whose farming activities in the past would not have been counted or recognised as work. ${ }^{4}$

\section{Employment Trends, 1995 - 2003}

In this section we evaluate the claim that the economy created two million net new jobs between October 1995 and March 2003, we investigate where employment has increased and we examine the rise in employment relative to the growth in labour supply. Our analysis is based on the same data from the OHS and LFS series used to generate official estimates on employment.

\section{(a) A two million net increase in employment?}

The total employment figures in Table 1 show that we arrive at approximately the same recorded net increase in total employment - slightly less than 1.95 million for the workingage population between 15 and 65 years. To help in assessing whether or not this

3 Respondents were prompted to report as employment "work on a farm or land, whether for a wage or as part of the household's farming activities" (see, for example, the 1997 OHS questionnaire, p.19 and the 1999 OHS questionnaire, p.15). $4 \quad$ Historically there have been inconsistencies in the way SSA has treated those engaged in small-scale farming. There has been a tendency to classify small-scale farmers as inactive rather than as employed, and particularly in the case of women, whose farming activities may have been seen as an extension of their household work. (See Posel and Casale, 2001 for more details on how subsistence farmers were treated in the earlier population censuses.) 
increase is credible, Table 1 also provides employment estimates disaggregated by the main types of employment. The figures are taken from the 1995, 1997 and 1999 OHSs and the September rounds of the LFS to avoid as far as possible seasonal effects. The LFS conducted in March 2003 is also included however, as the September 2003 data were not available at the time of writing, and because it is the survey on which the government based its job increase claim.

Estimates of work conducted outside the formal sector in subsistence farming and in the informal sector are likely to have been particularly affected by definitional changes that accompanied the introduction of the LFS. Erwin (2004) defends the government's statement by arguing that

"[m]ost of the rise in [non-agricultural] informal sector employment took place before the survey changeover, so the change in definition did not really seem to affect the numbers".

\section{Table 1: Employment trends, 1995-2003 (for individuals aged between 15 and 65 years, irrespective of hours worked or income earned)}

\begin{tabular}{|c|c|c|c|c|c|c|c|}
\hline & $\begin{array}{l}\text { OHS } \\
1995 \\
\end{array}$ & $\begin{array}{l}\text { OHS } \\
1997 \\
\end{array}$ & $\begin{array}{l}\text { OHS } \\
1999 \\
\end{array}$ & $\begin{array}{l}\text { LFS } \\
2000: 2\end{array}$ & $\begin{array}{l}\text { LFS } \\
2001: 2 \\
\end{array}$ & $\begin{array}{l}\text { LFS } \\
2002: 2 \\
\end{array}$ & $\begin{array}{l}\text { LFS } \\
2003: 1 \\
\end{array}$ \\
\hline $\begin{array}{l}\text { Subsistence agriculture } \\
\text { All other agriculture } \\
\text { Total agriculture }\end{array}$ & $\begin{array}{l}0 \\
943800 \\
(5768) \\
943800 \\
(5768)\end{array}$ & $\begin{array}{l}0 \\
411600 \\
(4583) \\
411600 \\
(4583)\end{array}$ & $\begin{array}{l}136300 \\
(3705) \\
673300 \\
(16747) \\
809600 \\
(10504)\end{array}$ & $\begin{array}{l}748300 \\
(7807) \\
644900 \\
(9654) \\
1393200 \\
(12992)\end{array}$ & $\begin{array}{l}217700 \\
(4651) \\
608700 \\
(9337) \\
826400 \\
(10873)\end{array}$ & $\begin{array}{l}373000 \\
(6183) \\
731400 \\
(10369) \\
1104400 \\
(12600)\end{array}$ & $\begin{array}{l}300000 \\
(4961) \\
710000 \\
(10888) \\
1010000 \\
(12402)\end{array}$ \\
\hline Domestic work & $\begin{array}{l}708400 \\
(6759)\end{array}$ & $\begin{array}{l}589400 \\
(5608)\end{array}$ & $\begin{array}{l}788200 \\
(9328)\end{array}$ & $\begin{array}{l}956000 \\
(11362)\end{array}$ & $\begin{array}{l}900100 \\
(10133)\end{array}$ & $\begin{array}{l}865300 \\
(10360)\end{array}$ & $\begin{array}{l}995400 \\
(14101)\end{array}$ \\
\hline $\begin{array}{l}\text { Formal self-employed } \\
\text { Informal self-employed } \\
\text { Total se If-employed }\end{array}$ & $\begin{array}{l}254800 \\
(5117) \\
447800 \\
(6152) \\
702600 \\
(8132)\end{array}$ & $\begin{array}{l}361500 \\
(5873) \\
552200 \\
(5622) \\
913700 \\
(8355)\end{array}$ & $\begin{array}{l}435700 \\
(8028) \\
898600 \\
(10356) \\
1334300 \\
(13174)\end{array}$ & $\begin{array}{l}430700 \\
(8704) \\
1128500 \\
(11648) \\
1559200 \\
(14762)\end{array}$ & $\begin{array}{l}440800 \\
(8920) \\
1231400 \\
(11935) \\
1672200 \\
(15076)\end{array}$ & $\begin{array}{l}469800 \\
(8036) \\
1158600 \\
(11733) \\
1628400 \\
(14264)\end{array}$ & $\begin{array}{l}485000 \\
(11318) \\
1209400 \\
(14714) \\
1694400 \\
(18566)\end{array}$ \\
\hline $\begin{array}{l}\text { Formal employees } \\
\text { Informal employees } \\
\text { Total employees }\end{array}$ & $\begin{array}{l}\text { Cannot be determined } \\
7137300 \\
(26702)\end{array}$ & $\begin{array}{l}6477200 \\
(21962) \\
609100 \\
(6142) \\
7086300 \\
(22886)\end{array}$ & $\begin{array}{l}6566900 \\
(29770) \\
705400 \\
(9066) \\
7272300 \\
(31128)\end{array}$ & $\begin{array}{l}6346000 \\
(31752) \\
702200 \\
(9718) \\
7048200 \\
(33237)\end{array}$ & $\begin{array}{l}6444000 \\
(30788) \\
615900 \\
(8974) \\
7059900 \\
(32078)\end{array}$ & $\begin{array}{l}6685800 \\
(30359) \\
543600 \\
(8415) \\
7229400 \\
(31514)\end{array}$ & $\begin{array}{l}7055900 \\
(39188) \\
633900 \\
(12340) \\
7689800 \\
(41085)\end{array}$ \\
\hline Individuals who hold more than one job & $\begin{array}{l}139100 \\
(3625)\end{array}$ & $\begin{array}{l}30100 \\
(1919)\end{array}$ & $\begin{array}{l}106200 \\
(3636)\end{array}$ & $\begin{array}{l}542000 \\
(8997)\end{array}$ & $\begin{array}{l}260600 \\
(7186)\end{array}$ & $\begin{array}{l}143900 \\
(4003)\end{array}$ & $\begin{array}{l}121100 \\
(5395)\end{array}$ \\
\hline Unspecified & 0 & $\begin{array}{l}73400 \\
(2150) \\
\end{array}$ & $\begin{array}{l}86900 \\
(2953) \\
\end{array}$ & $\begin{array}{l}240000 \\
(6310)\end{array}$ & $\begin{array}{l}124600 \\
(4672)\end{array}$ & $\begin{array}{l}75700 \\
(3261) \\
\end{array}$ & $\begin{array}{l}68800 \\
(5313) \\
\end{array}$ \\
\hline Total employed & $\begin{array}{l}9631200 \\
(29868)\end{array}$ & $\begin{array}{l}9104500 \\
(26220)\end{array}$ & $\begin{array}{l}10397500 \\
(37367)\end{array}$ & $\begin{array}{l}11738600 \\
(42133)\end{array}$ & $\begin{array}{l}10843800 \\
(39819)\end{array}$ & $\begin{array}{l}11047100 \\
(38982)\end{array}$ & $\begin{array}{l}11579300 \\
(49788)\end{array}$ \\
\hline Total employed less subsistence farmers & $\begin{array}{l}9631200 \\
(29868)\end{array}$ & $\begin{array}{l}9104500 \\
(26220)\end{array}$ & $\begin{array}{l}10261200 \\
(37174)\end{array}$ & $\begin{array}{l}10990300 \\
(41401)\end{array}$ & $\begin{array}{l}10626100 \\
(39540)\end{array}$ & $\begin{array}{l}10674100 \\
(38480)\end{array}$ & $\begin{array}{l}11279500 \\
(49540)\end{array}$ \\
\hline $\begin{array}{l}\text { Formal workers only } \\
\text { [employees and self-employed] }\end{array}$ & Cannot be determined & $\begin{array}{l}6838700 \\
(22808)\end{array}$ & $\begin{array}{l}7002600 \\
(30864)\end{array}$ & $\begin{array}{l}6776700 \\
(32983)\end{array}$ & $\begin{array}{l}6884800 \\
(32140)\end{array}$ & $\begin{array}{l}7155600 \\
(31427)\end{array}$ & $\begin{array}{l}7540900 \\
(40792)\end{array}$ \\
\hline $\begin{array}{l}\text { Informal workers only } \\
\text { [employees and self-employed] }\end{array}$ & & $\begin{array}{l}1161300 \\
(8370)\end{array}$ & $\begin{array}{l}1604000 \\
(13767)\end{array}$ & $\begin{array}{l}1830700 \\
(15170)\end{array}$ & $\begin{array}{l}1847300 \\
(14935)\end{array}$ & $\begin{array}{l}1702200 \\
(14445)\end{array}$ & $\begin{array}{l}1843300 \\
(19202)\end{array}$ \\
\hline
\end{tabular}

Notes: Estimates from 1995 to 2002 are weighted using 1996 populations census weights; 2003 estimates are weighted using 2001 population census weights. Standard errors are in parentheses. Subsistence farmers are those workers who are self-employed in agriculture and who are not registered. 
The figures in Table 1 do provide some support for this. Between October 1997 and October 1999 the total number of individuals employed in the informal sector (whether working for themselves or in other unregistered businesses and excluding agriculture) increased by 38 per cent, from 1161300 to 1604000 . With the survey changeover from October 1999 to September 2000, there was a recorded increase of 14 per cent (or 226700 additional workers), while between September 2000 and March 2003, the period over which definitions of employment were consistent, net employment in the informal sector increased by little more than 12000 , or less than one per cent. ${ }^{5}$

Erwin (2004) also claims that "[a]lmost all the rise in employment numbers after 2000 is attributable to the formal sector where jobs rose by over $700000 \ldots$... Again, the figures in Table 1 seem to confirm this: between September 2000 and March 2003 the number of individuals in formal sector jobs (excluding all agricultural workers, domestic workers and those with more than one job) rose from 6776700 to 7540900 , an increase of approximately 760000 workers.

Our estimations therefore are consistent with the arguments put forward to defend the government's claim of a "two million" increase in employment. However, there are other findings that should be added before we can more fully assess the credibility of the recorded growth in employment.

First, it is important to recognise that the identification of a trend in employment is very sensitive to the reference points used for the analysis. If the reference period chosen had been October 1995 to September 2002, then the total net increase in employment would have amounted to just over 1.4 million jobs. This implies that between September 2002 and March 2003 alone employment rose by over 500000 jobs, representing more than a quarter of the total increase in net employment over the eight year period. An important factor that may account for this sudden 'jump' in employment estimates is that the March 2003 survey is the first of the LFS series to be released with population weights based on the 2001 Census. It therefore seems acceptable to compare the end points of the series, i.e. 1995 and 2003, which are weighted to the closest census year (1996 and 2001 respectively). But the March 2003 LFS cannot reliably be compared to estimates from the earlier LFS surveys that are possibly biased downwards by inaccurate weights. ${ }^{6}$

\footnotetext{
5 A total informal sector employment figure is not available for 1995 because the OHS questionnaire in that year did not distinguish between employees working for registered versus unregistered businesses. 6 In fact, in SSA's statistical release on the LFS of March 2003, it is stated that: "...unlike previously, we do not compare the results to those of the previous rounds because the population estimates for this round are based on Census 2001, whereas in the previous releases they were based on Census 1996" (SSA, 2003:i). SSA note that they are currently in the process of benchmarking the earlier rounds of the LFS to the 2001 population census count.
} 
Second, we agree that a substantial part of the increase in employment may be 'real' in the sense that it is not a product of changing definitions of employment. However, for the reasons outlined below, we do not think that the contribution of definitional changes to the growth in employment estimates can be so easily dismissed.

It is clear from the disaggregated figures that estimates of subsistence farming are particularly erratic. In 1995 and 1997 all subsistence farmers, defined here ${ }^{7}$ as those who report being self-employed in agriculture but not registered, seem to have been excluded altogether from the employment count and, notwithstanding the prompt in 1997, were most likely to have been classified as inactive in these two surveys (SSA, 2001). From 1999 onwards subsistence farming is captured ${ }^{8}$, with a large increase recorded with the change over to the more detailed LFS questionnaire. However, the subsistence farming figures across the LFSs prove to be highly variable even with consistent definitions and methods of capture.

In light of this variability, and given that no subsistence farmers were counted in 1995, a more robust measure of the increase in employment between October 1995 and March 2003 would exclude subsistence agriculture. In this case, and as the figures reported in Table 1 indicate, the increase in total employment would not be two million, but rather a little over 1.6 million.

Even excluding subsistence farmers, it is possible that included in the 2003 employment estimates are individuals who were performing the same work before the survey changeover but who were not classified as employed prior to 2000. The category of employment that would have been particularly affected by clearer definitions of what counts as work is self-employment among individuals in the informal sector. Individuals whose 'business' or employment is unstable or marginal are most likely to have been overlooked by the earlier surveys, especially as respondents themselves might not have considered these survivalist activities as being real work.

\footnotetext{
7 Another way of defining subsistence farmers consistently across the surveys is by using the fourdigit International Standard Classification of Occupations (ISCO 88) code 6210 and, since 2003, the South African Standard Classification of Occupations (SASCO) code 6211 which represent "subsistence agriculture and fishery workers". Classifying subsistence farmers in this way, however, makes very little difference to the estimates. 8 It is not clear why subsistence farmers were identified in 1999 but not in 1997, given that the 1997 and the 1999 OHS questionnaires were identical. One possibility is that in 1999 enumerators were more carefully instructed to capture subsistence farming as employment. (For further discussion of estimates of subsistence farming using household survey data, see Posel and Casale, 2001; Aliber, 2003; Casale, 2003 and Muller and Posel, 2004.)
} 
The number of individuals self-employed in the non-agricultural informal sector grew from 447800 to 898600 over the period October 1995 to October 1999, an increase of just over 100 per cent. ${ }^{9}$ Between October 1999 and September 2000, the survey changeover, there was an increase of about 26 per cent (an additional 229900 individuals), while between September 2000 and September 2002, when definitions and population weights were consistent, there was an increase of only three percent from 1128500 to 1158600 individuals. ${ }^{10}$ It seems plausible that some of the recorded growth in informal sector self-employment that followed the introduction of the LFS in 2000 reflects more specific prompts to respondents, and the broadening of what counts as employment.

If we were to be conservative, therefore, and ignore both the rise in informal sector selfemployment from 1999 to 2000 when the survey changeover took place (229 900 jobs), as well as the growth in subsistence farming captured after 1995 (300 000 jobs), we would arrive at a 'lower bound' for the net increase in employment of approximately 1.4 million jobs over the eight-year period. ${ }^{11}$

\section{(b) Where has employment increased?}

Concerns about the data aside, perhaps a more important focus in evaluating the 'job increase claim' is what types of recorded jobs have grown over the period, rather than how many new jobs have been recorded. In his defence of the government's interpretation of employment estimates, Erwin (2004) stresses that the claim is not that "the two million net new jobs are all goods jobs in the formal sector". ${ }^{12}$ Perhaps more accurately, this could be restated as "less than half of the new jobs are jobs in the formal sector".

Between 1995 and 2003, employment grew across most types of employment, with the clear exception being the approximate 240000 fall in non-subsistence agricultural employment. If the number of net 'new' jobs increased by 1.95 million, then, given the fall in (non-subsistence) agricultural employment, the total number of new jobs recorded would have been approximately 2.2 million.

\footnotetext{
$9 \quad$ There was a substantial increase in self-employment in the informal sector between 1995 and 1997 (an additional 104400 individuals). While a more explicit prompt for what counts as work was included after 1995, perhaps accounting for some of the increase between 1995 and 1997, the OHS 1997 and OHS 1999 questionnaires were identical in the way in which they elicited information on employment. Unless the enumerators themselves placed more emphasis on capturing informal activities, this would suggest that a large part of the increase in the informal sector over this earlier period is likely to be real. 10 The tapering off of growth in informal self-employment from 2000 onwards may suggest that this type of informal sector employment is reaching the limit on its absorptive capacity. However, the trend needs to be reassessed when the LFS data are reweighted using more recent weights derived from the 2001 population census. 11 The standard error for this estimate is approximately 80000.

12 Erwin (2004) continues: "We do not claim we are solving the employment problem. Government's 10-year review and the ANC's election manifesto express concern about some effects of casualisation and outsourcing on the standards of living of workers and deal with the need to create more employment. But the bottom line is that there has been significant job growth since the mid-1990s". Note that we cannot use the household survey data to explore what portion of the increase in employment is associated with the outsourcing of work (see Esselaar, 2003 for further discussion).
} 
The figures in Table 1 show that approximately 750000 of this total 2.2 million increase in employment reflects the growth in informal sector self-employment; and almost 300000 derives from the expansion in domestic work. Between 1995 and 2003 therefore, more than one million additional jobs were 'created' in self-employment in the informal sector or in domestic work in private households; when subsistence farmers are included then this rises to 1.35 million.

Excluding almost 70000 individuals whose employment status could not be classified (Table 1), it is likely that most of the remaining 780000 increase in total recorded employment reflects growth in the formal sector, although we cannot be certain. The total number of employees (people working for others) increased by just over 550000 between 1995 and 2003. The 1995 OHS does not distinguish the sector of this employment and we therefore cannot separately measure the change in the number of individuals employed by others in the formal and informal sectors. However, trends between 1997 and 2003 would suggest that much of the increase derives from the expansion in the number of formal sector employees. Formal sector self-employment has also risen over the period, and accounts for the remaining growth in the total number of 'new' jobs reported.

In sum, if we take the data at face value, then the growth in formal sector employment, although not inconsiderable, accounts for less than forty percent of the total number of new jobs in the economy. ${ }^{13}$

\section{(c) The increase in labour supply}

The reported increase in employment cannot be considered in isolation from the dramatic increase in labour supply over the eight-year period. Taking the employment data as reported in the household surveys, Table 2 shows that the total economically active population based on a strict definition of unemployment (those actively searching for work) grew by more than five million individuals. Less than forty percent of these 'additional' labour force participants, who wanted to work and looked for work, actually found employment. ${ }^{14}$

\footnotetext{
13 Using a lower bound estimate of the total employment change (by excluding subsistence farmers captured after 1995 and the additional informal sector self-employed workers captured between 1999 and 2000), formal sector growth accounts for, at most, 47 percent of the new jobs recorded in the economy. 14 With cross-sectional household survey data, it is not possible to identify churning in the labour market and therefore to establish exactly how many new labour market entrants found employment over the period.
} 
Table 2: The total labour force and unemployment (Ue): 1995-2003

\begin{tabular}{|l|l|l|l|l|l|l|l|}
\hline & $\begin{array}{l}\text { OHS } \\
1995\end{array}$ & $\begin{array}{l}\text { OHS } \\
1997\end{array}$ & $\begin{array}{l}\text { OHS } \\
1999\end{array}$ & $\begin{array}{l}\text { LFS } \\
2000: 2\end{array}$ & $\begin{array}{l}\text { LFS } \\
2001: 2\end{array}$ & $\begin{array}{l}\text { LFS } \\
\mathbf{2 0 0 2 : 2}\end{array}$ & $\begin{array}{l}\text { LFS } \\
2003: 1\end{array}$ \\
\hline \multicolumn{7}{|c|}{ Strict labour force (employed + searching unemployed) } \\
\hline $\begin{array}{l}\text { Total labour } \\
\text { force }\end{array}$ & 11603100 & 11793200 & 14068700 & 15970500 & 15531400 & 16034000 & 16933700 \\
\hline $\begin{array}{l}\text { Total } \\
\text { unemployed }\end{array}$ & 1971900 & 2688700 & 3671200 & 4231900 & 4687600 & 4986900 & 5354200 \\
\hline Ue rate & 17.0 & 22.8 & 26.1 & 26.5 & 30.2 & 31.1 & 31.6 \\
\hline \multicolumn{7}{|c|}{ Broad labour force (employed + searching and non-searching unemployed) } \\
\hline $\begin{array}{l}\text { Total labour } \\
\text { force }\end{array}$ & 13648000 & 14468000 & 17169800 & 18250200 & 18556000 & 19276700 & 20259600 \\
\hline $\begin{array}{l}\text { Total } \\
\text { unemployed }\end{array}$ & 4017800 & 5363500 & 6772300 & 6511600 & 7712200 & 8229600 & 8680100 \\
\hline \begin{tabular}{l} 
Ue rate \\
\hline
\end{tabular}
\end{tabular}

Notes: Estimates are for all labour force participants aged between 15 and 65 years. The searching unemployed were identified as those who were willing to accept work and had actively searched for work in the four weeks prior to being interviewed.

When the labour force is expanded to include the non-searching unemployed (the broad definition of unemployment) then the increase in labour supply is close to 6.5 million, meaning that less than a third of the growth in labour supply translated into an increase in employment. ${ }^{15}$

The net increase in employment, whether it is estimated conservatively at 1.4 million or at almost two million jobs, has therefore been significantly smaller than the net increase in unemployment over the period. As a result, rates of unemployment have risen dramatically. In October 1995, 17 per cent of all economically active individuals were unemployed according to the strict definition of unemployment, and 29 per cent according to the broad definition; in March 2003 this had increased to 32 per cent and 43 percent respectively. 


\section{Implications of the Increase in Employment}

When evaluating trends in the labour market in South Africa, a more inclusive description is provided by looking not only at changes in employment and unemployment, but also at the returns that employment offers. Is income earned or generated sufficient to lift individuals (let alone families) out of poverty?

In Table 3, we report nominal and real average earnings between 1995 and 2003 across total employment and by employment categories. Overall, average earnings in nominal terms increased from approximately R2 182 to R2 881 a month. However, in real terms (and using 2000 as the base year), average monthly earnings declined over this eightyear period from R3 014 in 1995 to around R2 360 in 2003, a fall of more than twenty per cent. ${ }^{16}$

There are some concerns about the reliability of the earnings data in the household surveys that need to be pointed out here. In all of the survey years, individuals were given the option of reporting their earnings as either a point estimate or in an earnings bracket. The majority of the employed reported earnings as a point estimate (for example, 77 per cent in 1995 and 64 per cent in 2003). Where respondents did not provide this information, we used the midpoint of the bracket into which their earnings fell, with the exception of the highest and open-ended income bracket. Here we truncated the earnings distribution - if the bracket provided was, for example, R360 000 per annum or more, the individual was allocated an earnings value of R360 000. ${ }^{17}$ This may bias average earnings downwards, but less than half a percent of the employed reported earnings in the top bracket across the years. Furthermore, where the distribution of income is highly skewed, as is the case in South Africa, average earnings will overstate modal income. Re-estimating the change in earnings between 1995 and 2003 using geometric rather than arithmetic means produces an even larger decline in average real earnings of close to 29 per cent, from R1693 a month in 1995 to R1205 a month in 2003.

16 TheSouthAfrican ReserveBank(SARB)publishesdatawhichshowthat'remunerationperworker'hasbeen risingoverthisperiod (SARB, 2004). It is important to note that these figures derive from the Survey of Employment and Earnings (SEE) conducted by SSA, and are not comparable to those estimated from the household surveys. As explained earlier, the SEE is a firm-level survey which before 2002 was based on an outdated sample of firms, and which only captures those working in the formal non-agricultural sector and in businesses whose turnover exceeds a certain threshold level. It is possible that workers in this sample of firms experienced increased earnings on average. 17 While we used this method consistently across the years, a further problem arose in that the earnings brackets provided in the 1995 survey were different from those in the other survey years. In particular, the brackets at the upper and the lower ends of the earnings distribution differed. While this does introduce problems of comparability between 1995 and the other years, it is useful to note that in comparing 1997 to 2003, both years in which the earnings brackets provided were identical, a fall in real earnings of 16 percent was still recorded. 
Table 3: Estimates of nominal and real monthly earnings: $1995-2003$ (Rands)

\begin{tabular}{|c|c|c|c|c|c|c|c|c|c|c|c|c|}
\hline & \multicolumn{6}{|c|}{ Nominal } & \multicolumn{6}{|c|}{ Real } \\
\hline & $\begin{array}{l}1995 \\
\text { OHS }\end{array}$ & 1997 OHS & LFS 2000:2 & LFS 2001:2 & LFS 2002:2 & LFS 2003:1 & $\begin{array}{l}1995 \\
\text { OHS }\end{array}$ & 1997 OHS & LFS 2000:2 & LFS 2001:2 & LFS 2002:2 & LFS 2003:1 \\
\hline Subsistence agriculture & . & - & $\begin{array}{l}84 \\
(20)\end{array}$ & $\begin{array}{l}175 \\
(41)\end{array}$ & $\begin{array}{l}103 \\
(24)\end{array}$ & $\begin{array}{l}125 \\
(35)\end{array}$ & - & - & $\begin{array}{l}84 \\
(20)\end{array}$ & $\begin{array}{l}165 \\
(39)\end{array}$ & $\begin{array}{l}89 \\
(21)\end{array}$ & $\begin{array}{l}102 \\
(28)\end{array}$ \\
\hline All other agriculture & & - & $\begin{array}{l}681 \\
(42\end{array}$ & $\begin{array}{l}1061 \\
(70)\end{array}$ & $\begin{array}{l}954 \\
(63)\end{array}$ & $\begin{array}{l}1009 \\
(71)\end{array}$ & & . & $\begin{array}{l}681 \\
(42)\end{array}$ & $\begin{array}{l}1004 \\
(66)\end{array}$ & $\begin{array}{l}827 \\
(54)\end{array}$ & $\begin{array}{l}827 \\
(58)\end{array}$ \\
\hline Total agriculture & $\begin{array}{l}500 \\
(14)\end{array}$ & $\begin{array}{l}583 \\
(25)\end{array}$ & $\begin{array}{l}357 \\
(22)\end{array}$ & $\begin{array}{l}826 \\
(54)\end{array}$ & $\begin{array}{l}663 \\
(43)\end{array}$ & $\begin{array}{l}743 \\
(51)\end{array}$ & $\begin{array}{l}690 \\
(20)\end{array}$ & $\begin{array}{l}691 \\
(30)\end{array}$ & $\begin{array}{l}357 \\
(22)\end{array}$ & $\begin{array}{l}781 \\
(51)\end{array}$ & $\begin{array}{l}574 \\
(37)\end{array}$ & $\begin{array}{l}608 \\
(42)\end{array}$ \\
\hline Domestic work & $\begin{array}{l}424 \\
(12)\end{array}$ & $\begin{array}{l}572 \\
(16)\end{array}$ & $\begin{array}{l}524 \\
(11)\end{array}$ & $\begin{array}{l}509 \\
(9)\end{array}$ & $\begin{array}{l}486 \\
(10)\end{array}$ & $\begin{array}{l}578 \\
(13)\end{array}$ & $\begin{array}{l}585 \\
(17)\end{array}$ & $\begin{array}{l}677 \\
(19)\end{array}$ & $\begin{array}{l}524 \\
(11)\end{array}$ & $\begin{array}{l}481 \\
(9)\end{array}$ & $\begin{array}{l}421 \\
(9)\end{array}$ & $\begin{array}{l}473 \\
(10)\end{array}$ \\
\hline Formal self-employed & $\begin{array}{l}10196 \\
(921)\end{array}$ & $\begin{array}{l}7968 \\
(620)\end{array}$ & $\begin{array}{l}5424 \\
(285)\end{array}$ & $\begin{array}{l}6814 \\
(319)\end{array}$ & $\begin{array}{l}7618 \\
(322)\end{array}$ & $\begin{array}{l}9270 \\
(838)\end{array}$ & $\begin{array}{l}14081 \\
(1272)\end{array}$ & $\begin{array}{l}9441 \\
(765)\end{array}$ & $\begin{array}{l}5424 \\
(285)\end{array}$ & $\begin{array}{l}6447 \\
(301)\end{array}$ & $\begin{array}{l}6602 \\
(279)\end{array}$ & $\begin{array}{l}7599 \\
(687)\end{array}$ \\
\hline Informal self-employed & $\begin{array}{l}2427 \\
(165)\end{array}$ & $\begin{array}{l}1421 \\
(91)\end{array}$ & $\begin{array}{l}1154 \\
(56)\end{array}$ & $\begin{array}{l}1027 \\
(44)\end{array}$ & $\begin{array}{l}1140 \\
(55)\end{array}$ & $\begin{array}{l}1182 \\
(62)\end{array}$ & $\begin{array}{l}3352 \\
(227)\end{array}$ & $\begin{array}{l}1684 \\
(108)\end{array}$ & $\begin{array}{l}1154 \\
(56)\end{array}$ & $\begin{array}{l}971 \\
(42)\end{array}$ & $\begin{array}{l}988 \\
(47)\end{array}$ & $\begin{array}{l}968 \\
(51)\end{array}$ \\
\hline Total self-employed & $\begin{array}{l}4971 \\
(332) \\
\end{array}$ & $\begin{array}{l}3748 \\
(235) \\
\end{array}$ & $\begin{array}{l}2232 \\
(95)\end{array}$ & $\begin{array}{l}2390 \\
(100) \\
\end{array}$ & $\begin{array}{l}2723 \\
(108)\end{array}$ & $\begin{array}{l}3187 \\
(231) \\
\end{array}$ & $\begin{array}{l}68666 \\
(459) \\
\end{array}$ & $\begin{array}{l}4441 \\
(279) \\
\end{array}$ & $\begin{array}{l}2232 \\
(95)\end{array}$ & $\begin{array}{l}2261 \\
(95)\end{array}$ & $\begin{array}{l}2360 \\
(93)\end{array}$ & $\begin{array}{l}2610 \\
(189)\end{array}$ \\
\hline Formal employees & & $\begin{array}{l}2583 \\
(26)\end{array}$ & $\begin{array}{l}3161 \\
(43)\end{array}$ & $\begin{array}{l}3332 \\
(42)\end{array}$ & $\begin{array}{l}3671 \\
(45)\end{array}$ & $\begin{array}{l}3645 \\
(49)\end{array}$ & & $\begin{array}{l}3060 \\
(31)\end{array}$ & $\begin{array}{l}3161 \\
(43)\end{array}$ & $\begin{array}{l}3153 \\
(40)\end{array}$ & $\begin{array}{l}3182 \\
(39)\end{array}$ & $\begin{array}{l}2986 \\
(40)\end{array}$ \\
\hline Informal employees & $\begin{array}{l}\text { Cannot be } \\
\text { determined }\end{array}$ & $\begin{array}{l}1172 \\
(65)\end{array}$ & $\begin{array}{l}1037 \\
(57)\end{array}$ & $\begin{array}{l}1089 \\
(45)\end{array}$ & $\begin{array}{l}1025 \\
(57)\end{array}$ & $\begin{array}{l}1088 \\
(52)\end{array}$ & $\begin{array}{l}\text { Cannot be } \\
\text { determine }\end{array}$ & $\begin{array}{l}1389 \\
(77)\end{array}$ & $\begin{array}{l}1037 \\
(57)\end{array}$ & $\begin{array}{l}1030 \\
(43)\end{array}$ & $\begin{array}{l}888 \\
(50)\end{array}$ & $\begin{array}{l}891 \\
(42)\end{array}$ \\
\hline Total employees & $\begin{array}{l}2310 \\
(20)\end{array}$ & $\begin{array}{l}2230 \\
(22)\end{array}$ & $\begin{array}{l}2944 \\
(40)\end{array}$ & $\begin{array}{l}3127 \\
(39)\end{array}$ & $\begin{array}{l}3461 \\
(43)\end{array}$ & $\begin{array}{l}3425 \\
(45)\end{array}$ & $\begin{array}{l}3191 \\
(28)\end{array}$ & $\begin{array}{l}2642 \\
(27)\end{array}$ & $\begin{array}{l}2944 \\
(40)\end{array}$ & $\begin{array}{l}2958 \\
(37)\end{array}$ & $\begin{array}{l}2999 \\
(37)\end{array}$ & $\begin{array}{l}2805 \\
(37) \\
\end{array}$ \\
\hline Individuals who hold more than one job & $\begin{array}{l}4013 \\
(345)\end{array}$ & $\begin{array}{l}4383 \\
(771)\end{array}$ & $\begin{array}{l}2495 \\
(175)\end{array}$ & $\begin{array}{l}3240 \\
(311)\end{array}$ & $\begin{array}{l}2599 \\
(255)\end{array}$ & $\begin{array}{l}2712 \\
(339)\end{array}$ & $\begin{array}{l}5542 \\
(476)\end{array}$ & $\begin{array}{l}5193 \\
(913)\end{array}$ & $\begin{array}{l}2495 \\
(175)\end{array}$ & $\begin{array}{l}3066 \\
(294)\end{array}$ & $\begin{array}{l}2252 \\
(221)\end{array}$ & $\begin{array}{l}2221 \\
(277)\end{array}$ \\
\hline Unspecified & (0) & $\begin{array}{l}2585 \\
(702)\end{array}$ & $\begin{array}{l}2134 \\
(137)\end{array}$ & $\begin{array}{l}1908 \\
(205)\end{array}$ & $\begin{array}{l}1357 \\
(128)\end{array}$ & $\begin{array}{l}3980 \\
664)\end{array}$ & (0) & $\begin{array}{l}2707 \\
(832)\end{array}$ & $\begin{array}{l}2134 \\
(137)\end{array}$ & $\begin{array}{l}1805 \\
(194)\end{array}$ & $\begin{array}{l}1176 \\
(111)\end{array}$ & $\begin{array}{l}3259 \\
(544)\end{array}$ \\
\hline Total employed & $\begin{array}{l}2182 \\
(41)\end{array}$ & $\begin{array}{l}2373 \\
(31) \\
\end{array}$ & $\begin{array}{l}2292 \\
(29) \\
\end{array}$ & $\begin{array}{l}2594 \\
(32) \\
\end{array}$ & $\begin{array}{l}2783 \\
(33)\end{array}$ & $\begin{array}{l}2881 \\
(46)\end{array}$ & $\begin{array}{l}3014 \\
(38)\end{array}$ & $\begin{array}{l}2812 \\
(36)\end{array}$ & $\begin{array}{l}2292 \\
(29)\end{array}$ & $\begin{array}{l}2454 \\
(30)\end{array}$ & $\begin{array}{l}2412 \\
(29)\end{array}$ & $\begin{array}{l}2360 \\
(38)\end{array}$ \\
\hline Total empl. subtract subsistence agric. & (0) & (0) & $\begin{array}{l}2451 \\
(31)\end{array}$ & $\begin{array}{l}2646 \\
(32)\end{array}$ & $\begin{array}{l}2885 \\
(34)\end{array}$ & $\begin{array}{l}2960 \\
(47)\end{array}$ & (0) & (0) & $\begin{array}{l}2451 \\
(31)\end{array}$ & $\begin{array}{l}2504 \\
(30)\end{array}$ & $\begin{array}{l}2500 \\
(30)\end{array}$ & $\begin{array}{l}2424 \\
(38)\end{array}$ \\
\hline Formal workers only & $\begin{array}{l}\text { Cannot be } \\
\text { determined }\end{array}$ & $\begin{array}{l}2818 \\
(38)\end{array}$ & $\begin{array}{l}3290 \\
(44)\end{array}$ & $\begin{array}{l}3530 \\
(44)\end{array}$ & $\begin{array}{l}3890 \\
(47)\end{array}$ & $\begin{array}{l}3957 \\
(67)\end{array}$ & $\begin{array}{l}\text { Cannot be } \\
\text { determined }\end{array}$ & $\begin{array}{l}3339 \\
(45)\end{array}$ & $\begin{array}{l}3290 \\
(44)\end{array}$ & $\begin{array}{l}3340 \\
(42)\end{array}$ & $\begin{array}{l}3371 \\
(41)\end{array}$ & $\begin{array}{l}3241 \\
(55)\end{array}$ \\
\hline Informal workers only & $\begin{array}{l}\text { Cannot be } \\
\text { determined }\end{array}$ & $\begin{array}{l}1286 \\
(55)\end{array}$ & $\begin{array}{l}1109 \\
(41)\end{array}$ & $\begin{array}{l}1048 \\
(33)\end{array}$ & $\begin{array}{l}1103 \\
(41)\end{array}$ & $\begin{array}{l}1149 \\
(45)\end{array}$ & $\begin{array}{l}\text { Cannot be } \\
\text { determined }\end{array}$ & $\begin{array}{l}1523 \\
(65)\end{array}$ & $\begin{array}{l}1109 \\
(41)\end{array}$ & $\begin{array}{l}991 \\
(31)\end{array}$ & $\begin{array}{l}956 \\
(36)\end{array}$ & $\begin{array}{l}941 \\
(37)\end{array}$ \\
\hline
\end{tabular}

Notes: Estimates are for the employed between 15 and 65 years who have earnings information reported. The base year for real earnings calculations is 2000 . Standard errors of earnings estimates are presented in parentheses. In the OHSs, where there was more than one earnings estimate for individuals with more than one job, the highest earnings value reported was included in the calculations (in the LFS only earnings from the main job are reported). 
The aggregate earnings figures mask considerable differences by type of employment. Table $3^{18}$ shows that income earned in the informal sector and in domestic work is significantly lower than income earned in the formal sector, and furthermore that the gap has widened over time. For example, between 1997 (the first year for which we can identify total employment in the informal sector) and 2003, the ratio of earnings from informal sector and domestic work to earnings from formal sector work decreased from 0.66 to 0.40. This is because nominal (let alone real) earnings in the informal sector (among both employees and the self-employed) fell over this period, and domestic workers' wages fell in real terms. Among formal sector employees, average earnings do not seem to have changed significantly over the period in real terms, while among those in formal self-employment there was a significant net decline over the period.

Figure 1. Earnings distribution of the informally self-employed: 1995 and 2003

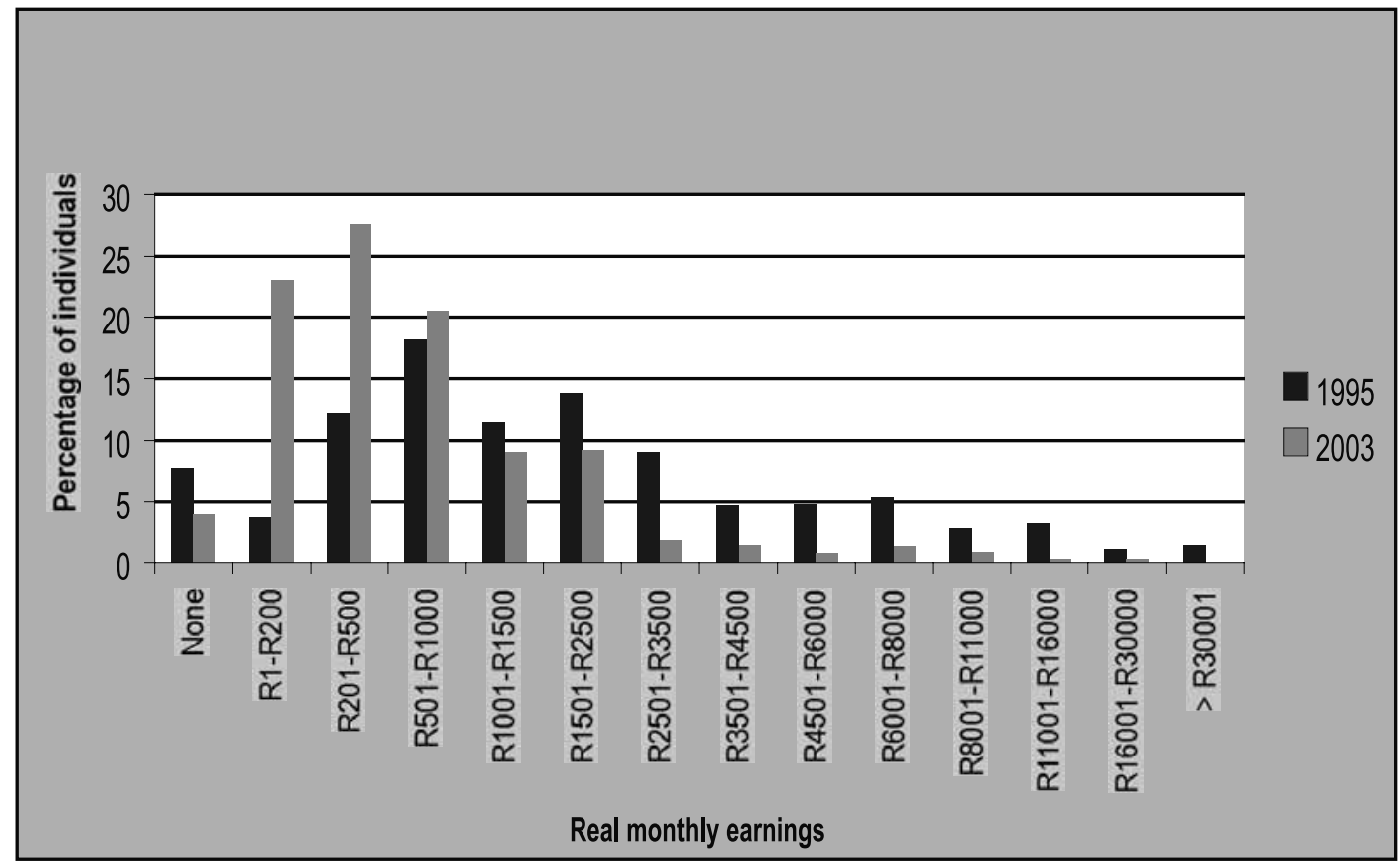

$18 \quad$ Earnings in 1999 have been excluded from the series in Table 3 as the OHS questionnaire in that year only asked for the gross earnings of all those in self-employment, whereas in the other surveys used in this analysis earnings net of expenses are available. 
Particularly noteworthy is that the largest relative fall in average real earnings occurred in the category of employment that has shown the greatest job growth - informal sector selfemployment. In 2003 average real earnings among this group of the employed stood at less than a third of the 1995 value. Just as part of the recorded growth in informal sector self-employment may not be real, so part of the fall in average returns to this employment may be due to the more efficient capture of low-paid work. The introduction of the LFS in 2000 was associated with a substantial drop in earnings in informal sector self-employment. However, greater competition in self-employment over the eight-year period, and an increase in survivalist activity, would also be expected to depress earnings.

The limited earnings power of the self-employed in the informal sector is clearly visible in Figure 1. While there is some potential for individuals to earn high returns in this type of employment, the distribution is strongly skewed towards the lower end of the earnings distribution and has shifted further to the left between 1995 and 2003.

A large and growing number of working individuals in South Africa are not able to escape poverty through employment. Rather, the increase in employment in South Africa has been associated with a considerable rise in the number of the working poor. In Table 4 we report the incidence of poverty amongst the employed using two poverty lines. The lower, more conservative, poverty line is based on $\$ 2$ a day (equal to R420 per month ${ }^{19}$ in 2003 prices, and a real income of R344 per month with 2000 as the base year). The higher, more 'generous', poverty line reflects the official minimum wage for a full-time domestic worker in an urban area in South Africa (equal to R713 per month in 2003 prices and R584 in 2000 prices). Because of concerns with the population weights used for the intervening years, we have presented statistics for 1995 and 2003 only.

Whichever poverty line is adopted the extent of poverty among the employed is shown to have increased considerably. In fact, over the eight-year period, the number of the employed living in poverty more than doubled: from just over 900000 to approximately two million individuals based on the conservative poverty line; and from 1.6 million to 3.2 million using the more generous line. In 2003, almost twenty percent of those with employment were earning less than the equivalent of $\$ 2$ a day, and almost 30 per cent reported earnings that were lower than the minimum wage for a domestic worker. 
Table 4: Number and proportion of workers falling below a poverty line: 1995 and 2003

\begin{tabular}{|c|c|c|}
\hline & 1995 OHS & LFS 2003:1 \\
\hline Real poverty line $\mathrm{A}$ & \multicolumn{2}{|c|}{$\$ 2$ per day (R344 per month in 2000 prices) } \\
\hline $\begin{array}{l}\text { All employed } \\
\text { Number } \\
\text { Proportion }\end{array}$ & $\begin{array}{l}910900 \\
9.6\end{array}$ & $\begin{array}{l}2022300 \\
18.8 \\
\end{array}$ \\
\hline $\begin{array}{l}\text { Informal self-employed } \\
\text { Number } \\
\text { Proportion }\end{array}$ & $\begin{array}{l}73500 \\
18.1 \\
\end{array}$ & $\begin{array}{l}486000 \\
42.0\end{array}$ \\
\hline $\begin{array}{l}\text { All employed excluding informal sector self-employed } \\
\text { Number } \\
\text { Proportion }\end{array}$ & $\begin{array}{l}837400 \\
9.2 \\
\end{array}$ & $\begin{array}{l}1536300 \\
16.0 \\
\end{array}$ \\
\hline $\begin{array}{l}\text { All employed excluding subsistence farmers } \\
\text { Number } \\
\text { Proportion }\end{array}$ & $\begin{array}{l}910900 \\
9.6 \\
\end{array}$ & $\begin{array}{l}1736000 \\
16.6 \\
\end{array}$ \\
\hline Real poverty line B & \multicolumn{2}{|c|}{ R584 per month (in 2000 prices) } \\
\hline $\begin{array}{l}\text { All employed } \\
\text { Number } \\
\text { Proportion }\end{array}$ & $\begin{array}{l}1597700 \\
16.9 \\
\end{array}$ & $\begin{array}{l}3207500 \\
29.8 \\
\end{array}$ \\
\hline $\begin{array}{l}\text { Informal self-employed } \\
\text { Number } \\
\text { Proportion }\end{array}$ & $\begin{array}{l}108900 \\
26.7 \\
\end{array}$ & $\begin{array}{l}670100 \\
57.9 \\
\end{array}$ \\
\hline $\begin{array}{l}\text { All employed excluding informal sector self-employed } \\
\text { Number } \\
\text { Proportion }\end{array}$ & $\begin{array}{l}1488800 \\
16.5\end{array}$ & $\begin{array}{l}2537400 \\
26.4\end{array}$ \\
\hline $\begin{array}{l}\text { All employed excluding subsistence farmers } \\
\text { Number } \\
\text { Proportion }\end{array}$ & $\begin{array}{l}1597700 \\
16.9\end{array}$ & $\begin{array}{l}2919900 \\
27.9\end{array}$ \\
\hline
\end{tabular}

Notes: Estimates are for the employed aged between 15 and 65 years. So as not to bias the estimates of poverty downwards, we have excluded all those employed but without earnings information reported.

In light of the earnings data presented above, it is not surprising that the extent of poverty among those with informal sector self-employment is particularly high and that it increased significantly over the period. Between 1995 and 2003, the number of these workers whose real income was less than $\$ 2$ a day expanded by more than 500 per cent. Furthermore, by 2003 , almost 60 per cent of the self-employed in the informal sector reported real income of less than R584 per month.

It is possible that earnings estimates in 2003 are being biased downwards by changes in data capture. First, part of the increase in informal survivalist activities may not be real and second, subsistence farmers (who are also very low earners) ${ }^{20}$ have been included

20 Income earned from small-scale/subsistence farming is substantially lower than from all other types of employment. Because the surveys do not ask for an imputed value for subsistence production, only cash earnings are being picked up here and 'returns' to this employment would also be underestimated. In fact, many subsistence farmers report zero cash earnings. 
in the calculation for 2003 but they were not counted in 1995. In Table 4 therefore we present two further estimates of poverty - one for all the employed excluding those with self-employment in the informal sector, and one that excludes subsistence farmers. As expected, the incidence of poverty falls for both these measures, but still approximately 16 per cent of the restricted samples of the employed report earnings below our conservative poverty line. Income earned through employment forms a significant part of the population's access to resources (see, for example, Leibbrandt, Bhorat and Woolard, 2001). ${ }^{21}$ Between 1995 and 2003, the decline in average earnings has been relatively greater than the net increase in employment. As a result, the total monthly wage or earnings bill in real terms has fallen, from approximately R29 billion in 1995 to R27.3 billion in 2003. In Table 5 we highlight the implications of this fall.

\section{Table 5: The total real earnings bill (in 2000 prices) and the total population (<65 years): 1995 and 2003}

\begin{tabular}{|l|l|l|}
\hline & 1995 OHS & LFS 2003:1 \\
\hline Total earnings bill & 29028000000 & 27328000000 \\
\hline Total population (<65 years) & 38037600 & 44025800 \\
\hline $\begin{array}{l}\text { Average earnings per individual (<65 years) } \\
\text { (Rands) }\end{array}$ & 763 & 621 \\
\hline
\end{tabular}

Note: The total earnings bill has been calculated for all those employed between the ages of 15 and 65 years.

Between 1995 and 2003, the total population aged younger than 65 years increased from 38 million to 44 million. In 2003 therefore, a smaller total real earnings bill would have been 'shared' among this larger population. Estimated per capita earned income declined by almost 19 per cent, from an average real income of R763 per month in 1995 to R621 per month in 2003. ${ }^{22}$

The above exercise illustrates a fall in the total size of the 'earned income' pie in the country. However, the fall has not been evenly distributed across all South Africans. We conclude this section by briefly considering labour market trends and earnings across the four population groups in South Africa.

21 Statetransfers(particularlytheOldAgePension(OAP), thechildsupportgrantand the disabilitygrant)areanotherkeycomponent of total resources in a household. However, data on the value of this income received are not captured in the OHS or LFS used here.

22 Those of pension age are excluded from the calculations here as it is assumed that they receive a pension (if not private then the OAP), and are thus not dependent on income from the employment of working-age individuals. 
The disaggregated data provided in Table 6 highlight large inequalities across labour market participants. These inequalities are most pronounced between Africans and Whites. In 1995, total employment among Africans was more than 200 per cent greater than total employment among Whites. However, the gap in average monthly real earnings across these groups was even larger - employed Whites earned almost 250 per cent more than employed Africans. Consequently, the total monthly real earnings bill accruing to Whites was greater than that accruing to Africans (R13 billion compared to R12.3 billion).

Between 1995 and 2003, total employment among both Africans and Whites increased, but the increase was much larger among Africans (1.6 million compared to approximately 26 000). The estimate for Africans may be biased upwards because they are over-represented in those categories of employment (subsistence farming and informal sector selfemployment) that have been captured more efficiently as the surveys have progressed (Casale, 2003).

Furthermore, although unemployment rates increased by relatively more among Whites over the period, this was from a far lower base, and rates of unemployment among Africans remained much higher. In 2003, 50 per cent of all economically active Africans were unemployed according to the broad definition compared to ten percent of Whites. 


\section{Table 6: Employment data by population group, 1995 and 2003}

\begin{tabular}{|c|c|c|}
\hline & 1995 O HS & LFS $2003: 1$ \\
\hline \multicolumn{3}{|l|}{ Africans } \\
\hline Total employment & 6200600 & 7830900 \\
\hline Total unemployment (strict) & 1646500 & 4689100 \\
\hline Total unemployment (broad) & 3553700 & 7765500 \\
\hline Average real earnings (2000 prices) & $\begin{array}{l}\mathrm{R} 1978 \\
(23)\end{array}$ & $\begin{array}{l}\mathrm{R} 1484 \\
(21)\end{array}$ \\
\hline Total real earnings bill $(\mathrm{pm})$ & R12 264800000 & $\mathrm{R} 11621000 \quad 000$ \\
\hline Total individuals (<65 years) & 29498600 & 35042400 \\
\hline Average earnings per individual ( $<65$ years) & R416 & R332 \\
\hline \multicolumn{3}{|l|}{ Indians } \\
\hline Total employment & 364900 & 423900 \\
\hline Total unemployment (strict) & 41800 & 124900 \\
\hline Total unemployment (broad) & 53300 & 147900 \\
\hline Average rea l earnings (2000 prices) & $\begin{array}{l}\text { R4279 } \\
(147) \\
\end{array}$ & $\begin{array}{l}R 4400 \\
(590)\end{array}$ \\
\hline Total real earnings bill & R1 561400000 & R1 865200000 \\
\hline Total individuals (<65 years) & 1008500 & 1123200 \\
\hline Average earnings per individual ( $<65$ years) & R1548 & R1660 \\
\hline \multicolumn{3}{|l|}{ Coloureds } \\
\hline Total employment & 1160200 & 1383900 \\
\hline Total unemployment (strict) & 215100 & 391200 \\
\hline Total unemployment (broad) & 321300 & 549600 \\
\hline Average real earnings (2000 prices) & $\begin{array}{l}\text { R2071 } \\
(37) \\
\end{array}$ & $\begin{array}{l}\text { R2084 } \\
(68) \\
\end{array}$ \\
\hline Total real earnings bill & R2 402800000 & R2 884000000 \\
\hline Total individuals (<65 years) & $3506 \quad 500$ & 3952000 \\
\hline Average earnings per individual ( $<65$ years) & R685 & $\mathrm{R} 730$ \\
\hline \multicolumn{3}{|l|}{ Whites } \\
\hline Total employment & 1905500 & 1930700 \\
\hline Total unemployment (strict) & 68500 & 148000 \\
\hline Total unemployment (broad) & 89500 & 214700 \\
\hline Average rea I earnings (2000 prices) & $\begin{array}{l}\text { R6840 } \\
(165) \\
\end{array}$ & $\begin{array}{l}\text { R6372 } \\
(141) \\
\end{array}$ \\
\hline Total real earnings bill & $\mathrm{R} 13033600 \quad 000$ & $\mathrm{R} 12302400 \quad 000$ \\
\hline Total individuals (<65 years) & 4024000 & 3888000 \\
\hline Average earnings per individual ( $<65$ years) & R3239 & R3164 \\
\hline
\end{tabular}

Notes: Earnings are for employed individuals between 15 and 65 years.

12450 individuals (weighted) in the LFS 2003:1 do not have population group information and were excluded from the calculations. All earnings are monthly values. Standard errors of average real earnings are in parentheses. 
Average real earnings for both population groups also decreased, but the fall was significantly greater for Africans (25 per cent compared to 7.2 per cent). The growth in employment was not sufficient to offset the drop in real earnings and the total monthly real earnings bill therefore decreased for both Africans and Whites (and by relatively more for Africans).

Over the same period, the total population younger than 65 years fell slightly among Whites (although by relatively less than the drop in the total real earnings bill), but it increased by more than five million among Africans. Consequently, in 2003 a smaller total earnings bill was shared among a larger African population. Average monthly real earned income per African individual therefore decreased significantly between 1995 and 2003 (by twenty percent), and the gap between Africans and Whites widened further. In 1995, per capita real earned income for Whites was almost eight times that for Africans; but in 2003, this had increased to almost ten times.

There have been some improvements, on average, in labour market outcomes for the other two population groups. Average real earnings for both Indians and Coloureds with employment rose, although not significantly. Total employment among these groups also grew, and as a result, the total real earnings bill increased. This increase was greater than that for the total population younger than 65 years, and average per capita real earned income therefore rose for both Indians (from R1548 to R1660) and Coloureds (R685 to R730). Indians continue to earn significantly more on average than Coloureds and Africans, but still significantly less than Whites.

\section{Conclusion}

Between 1995 and 2003, data captured on employment in the OHS/LFS series do record an almost two million net increase in total employment in South Africa. In this paper, however, we have argued that this measure is a generous estimate of the growth in 'new' jobs in the economy. When we account for changes in data capture and the broadening of what counts as work in the household surveys, then the net increase in total employment would be more conservatively estimated at approximately 1.4 million new jobs.

Even if we were to accept that all of the reported increase in employment is real, however, the claim of job growth cannot be presented without considerable further qualification. Less than half of the total number of 'new' jobs recorded reflects employment in the formal sector; more than half therefore is accounted for by an increase particularly in selfemployment in the informal sector, in domestic work, and in subsistence farming, all types of work associated with very low returns. 
The growth in employment also must be considered in the context of a dramatically larger increase in labour supply among working-age individuals. Over the eight-year period, less than a third of the increase in labour supply (broadly defined) translated into an increase in employment. If the number of employed rose by the order of two million, then the number of unemployed grew by approximately 4.5 million, according to the broad definition of unemployment.

Furthermore, among those with employment, average real earnings fell by more than twenty per cent. The extent of the fall is reflected in an increase in poverty among the employed. Between 1995 and 2003, the number of the employed earning less than $\$ 2$ a day doubled, from approximately 900000 to more than two million individuals. In 1995, 17 per cent of those with employment reported real earnings that were less than the official monthly wage for a domestic worker; by 2003 , this had increased to just under 30 per cent.

The rise in the number of the working poor has been largest among that type of employment that has shown the greatest growth - in 1995, 18 per cent of all those with informal sector self-employment earned less than \$2 a day, but in 2003 this had more than doubled to 42 per cent.

The total increase in employment has been relatively smaller than the decline in average monthly real earnings. As a result, between 1995 and 2003 the total monthly real earnings bill fell. In 2003, a significantly smaller earned income pie was therefore being shared among a significantly larger population (younger than 65 years), and consequently average per capita real earned income in South Africa declined.

The fall in average real earnings has not been consistent across all population groups in South Africa. There has been a small improvement for Indians and Coloureds. Average real earnings for Whites have fallen slightly, but the largest reported decline is among Africans, where average real earnings fell by almost 25 per cent over the period. Consequently, the increase in employment between 1995 and 2003 appears to have reinforced the disadvantaged position of Africans, on average, in the labour market.

In sum, claims of rising employment in South Africa cannot be assessed in isolation from a significantly larger rise in unemployment, the growth particularly of informal sector selfemployment, and declining average real earnings chiefly among Africans. 


\section{References}

Aliber, M (2003). "Small-Scale Agriculture as Revealed by the Labour Force Survey". Unpublished mimeo, Human Sciences Research Council.

ANC (2004). "Employment I: We need a people's contract to create work", ANC Today, Volume 4, No. 9, 5-11 March 2004.

(2004). "Employment II: The myth of jobless growth", ANC Today, Volume 4, No. 9, 5-11 March 2004.

Bell, T. (2004). "Unions and researchers slam government over claims of jobs growth", Published on Business Report website, 15 February.

Bhorat, H. (1999). "The October Household Survey, Unemployment and the Informal Sector: A Note", The South African Journal of Economics, 67(2): 320-326.

Casale, D. (2003). The Rise in Female Labour Force Participation in South Africa: An Analysis of Household Survey Data, 1995-2001. Unpublished Ph.D thesis. University of Natal.

and Posel, D. (2002). "The feminisation of the labour force in South Africa: an analysis of recent data and trends", The South African Journal of Economics 70(1): 156-184.

Dawes, N. (2004). "DA rubbishes ANC jobs claims", This Day, 8 March.

Erwin, A. (2004). "Doomsayers take liberties with facts on employment", Minister of Trade and Industry in Sunday Independent, Business Report, 15 February.

Esselaar, J. (2003). Outsourcing in the South African context: Evidence from two case studies. Unpublished Masters thesis. University of Natal.

Klasen, S. and Woolard, I. (1999). "Levels, Trends and Consistency of Measured Em ployment and Unemployment in South Africa", Development Southern Africa, 16: 3-35.

Leibbrandt, M., Bhorat, H. and Woolard, I. (2001). "Household Inequality and the Labour Market in South Africa", Contemporary Economic Policy 19(1): 73-86.

Mdladlana, M.M.S. (2004). "The debate on the President's State of the Nation Address", Speech by Minister of Labour in Parliament, 10 February, Cape Town. 
Muller, C. (2003). Investigating South African's Informal Sector: Measurement, Partici pation and Earnings. Unpublished Masters thesis. University of Natal. and Posel, D. (2004). "Concerns with measuring informal sector employment: An analysis of national household surveys in South Africa, 1993-2001", Studies in Economics and Econometrics 28(1):1-20.

Nattrass, N. (2000). "The debate about unemployment in the 1990s", Studies in Economics and Econometrics, 24(3): 73-89.

Posel, D. and Casale, D. (2001). "Gender aggregates: women subsistence farmers affect the unemployment count", Agenda, 49:82-88.

Schlemmer, L. and Levitz, C. (1998). "Unemployment in South Africa. The Facts, the Prospects, and an Exploration of Solutions", Johannesburg: South African Institute of Race Relations.

South African Reserve Bank (2004). Quarterly Bulletin, September 2004, No. 233, Pretoria.

Standing, G.; Sender, J. and Weeks, J. (1996). Restructuring the Labour Market: the South African Challenge. An ILO Country Review. International Labour Office. Geneva.

Statistics South Africa (2000). "Comparative labour statistics. Survey of Employment and Earnings in selected industries", Discussion Paper 2, December, Pretoria.

(2001). "Comparative labour statistics. Labour Force Survey: first round pilot February 2000", Discussion Paper 1, March, Pretoria.

(2002). "Comparative labour statistics. Survey of Employment and Earnings in selected industries", Discussion Paper, September, Pretoria.

(2004). Statistical release P0275.

Wray, Q. (2004). "Erwin digs in his heels on job increase data", Published on Business Report website on 23 February. 